\title{
Carlo Bavagnoli’s and Mario Dondero’s Photojournalism in the Neorealist Italy in the Post-second World War (1950-1959): An Uncensored Gaze
}

\author{
Rita Ladogana \\ University of Cagliari, Sardinia, Italy
}

\begin{abstract}
The article describes the activity of two Italian photographers: Carlo Bavagnoli (1932) and Mario Dondero (1928). In particular, it focuses on their debuts in the world of photojournalism in Italy since the early 1950s. First, it offers an overview of the national photographic research in the post-Second World War, underlining a significant evolution compared with the past and the complexity of the directions undertaken. Then, in the outlined context, it studies the work of the two photographers and their approach to a socially active photography, dwelling mainly on the relationships interwoven with the ruling publishing system. It also underlines the elements characterizing the nature of their reportages and the distance from an idea of image exploitation, derived from an always increasing interference of the political control over the images destined to mass communication. Both Dondero and Bavagnoli avoid any tendency to spectacularization and to the representative models typical of the common neorealist orientation, proposing an information founded on the effectiveness of narration, on the concreteness and immediacy of evidence; the first collaborations with the most progressive magazines testify the peculiarity of a method that both will coherently develop in the experiences matured outside the Italian context.
\end{abstract}

Keywords: photojournalism, Italy, neorealism, Carlo Bavagnoli, Mario Dondero

\section{Introduction}

The Italian overview of photojournalism after World War II appears very complicated. In this multiplicity of addresses an important role covers the activities of photographers free lance, who asked for autonomy in the ruling publishing system.

Examining the beginnings of Carlo Bavagnoli and Mario Dondero means to understand their conception of the image and the importance that took their photographic language that was incisive and direct at the same time. In the extent of their experiences, the first production is configured as a setting of the method and a belief that photographers will never abandon in the next evolution of their language.

The long journey of the Italian photographers Carlo Bavagnoli (1932) and Mario Dondero (1928) began during the great season of Italian photojournalism in the post-second World War; a historical moment that started

Rita Ladogana, Researcher in History of Contemporary Art, Department of History, Cultural Heritage and Territory, University of Cagliari. 
in 1945, following the Liberation from 20 years of fascist dictatorship, and it continued until the end of the 1950s, marking a deep caesura with the past and preparing the ground for a new way of conceiving the photographic means. The potential of the photographic image in its documentary function was understood with a delay compared to the rest of the Western world, while examining the discovery of a realistic narrative founded on the direct and immediate taking of great current events; after two decades of unsaid truth an urgent need to know and "see" the reality of the country started to impose itself. On the whole the evolution of the photographic language, despite the complexity and the multiformity of the established trends, photographic image looked oriented towards the celebration of image's political value of evidence and condemnation, and towards a kind of neorealist attitude consistent with the trends typical of the phenomenon itself in the national context (Lucas, 2004). In fact, Neorealism, besides the uncountable nuances it acquired from the literary world to the cinematographic domain, was essentially founded on a direct and critical relationship with reality and on an indeclinable necessity of a "commitment" towards the transforming society, headed towards a deep mutation of the social and political setting. In the new cultural climate, arisen as expression of a deep historical fracture, manifestation "of a new way of looking at the world, a new ideology and morality typical of the antifascist revolution”, in a short time, became evident the fundamental importance acquired by image and, above all, its relationship with the text at the level of mass communication. In a few years, several newspapers were born; dailies and information periodicals proliferated so remarkably that, in proportion to the inhabitants, they surpassed those in the other European countries. Already by the end of the 1950s, in Italy, in some occasions photography succeeded in finding again the sense of its real representative vocation, in contrast with pictorialism and the formal artificialities that had dominated large part of the previous research; since 1939 the development of photojournalism had been experimented by Federico Patellani's "photo-tests" on the weekly Tempo, which immediately displayed a strong connotation towards social commitment (Del Buono, 2001). Its inheritance was picked up by Elio Vittorini's Il Politecnico, whose first issue was published in Milan in 1945, it was a magazine that tried to promote the development of photonarrative while inspiring itself on the photographic revolution of the American press and on the European examples of the Bauhaus, asserting the primary importance of a dialogue between images above any other requirement. Several magazines born between the end of the 1950s and the early 1950s looked at Politecnico's example, from Europeo to Arrigo Benedetti's Espresso, from Pannunzio's Il Mondo to Illustrazione Italiana. This approach to reality with a typically neorealist orientation, fully welcomed by the new editors and photographers, found its direct precedent in the model represented by the great photographers involved in the American project of the Farm Security Administration (1935), basically founded on an idea of propagandist documentary photography, designed to moving and stirring consciences about the social issues that had troubled the rural areas during the New Deal reform (Lugon, 2008). In the Italian context, as Francesco Faeta very well summarized, “(...) the representation of reality should have enabled the emancipation of the social sphere with a more or less accentuated degree of political participation by the single authors (...)” (Faeta, 2009); a condition that strongly exposed to the proven risk of choosing "deformed" images, in line with a production clearly conditioned by the complex tensions existing within the political-social context saw the Front of the Left opposed to the Democrazia Cristiana. A predilection for a photographic evidence always more subordinate to the choices of the commissioners imposed itself, with the subsequent confirmation of an instrumental use of images, leaning on stereotyped photos. We can quote the example of large part of the left-wing press always more 
oriented, since the early 50s, to the publication of propagandistic photos of mass of workers and protest demonstrations, with the intellectuals' alignment to the needs of politics and to the concept of a populist photography (Lucas, 2004). In most cases, the editor's close examination acquired a determining weight in limiting the photographer's free opinion, especially with regard to the order the sequence of images tied to the photographic narrative should have taken; in fact, the new orientation preferred an isolated photo to a narration through images, bound to become always more rare. To that extent, Patellani's testimony is meaningful, he was a prominent figure in the years of change and in an interview in the early 1960s reported how hard and always more difficult it was for "true photographs, those that by demand are considered "non-conformists", to meet an understanding and an interest”.

At the same time, with a peculiar increase that was noticed since the early 50s, another editorial orientation imposed itself, opposed to committed photojournalism and escaping from both social interest and ideological conditioning; an orientation culturally tenuous that had affected especially some bourgeois press, projected towards the refusal of the neorealist portrait and the condemnations of misery in order to promote the narration of a dream reality, an image of affluence and of a rich and opulent life. From the golden fairytale of film stars to beauty contests and snap-shots of royal families, the model proposed to the readers had to instill an optimistic approach to life while living down the problems troubling Italy and supporting a process of recognition and identification in an ideal and desirable dimension. An escapist photojournalism that had caused the fortunes of several illustrated news magazines, such as Gente and Oggi, responsible of a push towards escapism, which had also concerned cinema, and the consolidation of an idea of journalism meant as a tool for steering a large part of the social texture, starting from the middle class, away from political commitment.

In this brief description of a post-war Italy lighted up by experimental vivacity, but also by regularization processes and opposing pushes, we can recognize some groups of photographers, which we could define "independent", active in the production of a free journalistic information trying to release itself from the impositions of the established system. They usually were young university students, educated and intellectually vivacious, motivated by a need of participation and full commitment to the transformation processes of the national socio-political context; youths that wanted to launch their professional challenge defending the liberty of expression and opposing the predominance of a stereotyped image, who have thus contributed to writing the interesting story of a marginal photojournalism that was to influence the future generations of free-lance photographers (Lucas, 2004). A line of research that often turned into a story of disappointment and that did not find understanding and a chance of expression in the Italian press, transforms itself in a tale of escapes towards different places or choices of paths alternative to the dominating condition of documentarism. One of the most emerging groups of photographic experimentation in the national context, for the specificity of the promoted proposal and the quality of the results produced, was born in the early 50s in Milan's feverish cultural climate, then a center of major production and diffusion of the Italian publishing. The place where the partnership started was the historical bar Jamaica, in the very lively Brera area, a cultural heaven frequented by literates, journalists, artists, and photographers that met for discussing and reflecting, in a continuous development of new ideas and perspectives; at the base of this there was a great intellectual commitment, a will of thinking at the future and, above all, a will of growing and continuously confronting themselves with the higher models (Agliani, Dangelo, Lucas, \& Tadini, 2012). Carlo Bavagnoli and Mario Dondero distinguished themselves among the photographers, 
alongside Ugo Mulas, Giulia Nicolai, and Alfa Castaldi, all strongly united by a solid friendship and pushed by the aspiration to a similar ideal of visual language. The regular meetings often turned into work groups, with real peregrinations in the search of places and objects to photograph; naturalness, concreteness, and truth constituted the key points from which departing in order to achieve a realistic reportage far from aestheticisms and ideological conditionings. "We were interested in all that was image”, Bavagnoli tells,

...in particular in the international magazines, but also in Cinema Nuovo, where Guido Aristarco went on publishing the famous "photo-documentaries". The stroke of luck came when Alfa Castaldi found a whole trunk of the Magnum photographers. (...) We spent the afternoons looking at these prints (...) Then we went around Milan taking photographs, often at the central station, but also out-of-town. We worked for Soncini's agency, Interprix, which paid us in advance for the materials. We did go selling the images to the newspapers, (...) (Colombo \& Piovani, 1980)

Robert Capa and Henri Cartier-Bresson were considered by Dondero as "the main masters"; and Life, of which Alfa Castaldi owned a large collection of issues, was the American magazine that became an undisputable model of free approach to photojournalism, continuously consulted and celebrated by this group of self-educated photographers (Guerra, 2011).

Luciano Bianciardi had first reported about the connection between Bavagnoli and Dondero, prominent figures of the group, in his biting novel La vita agra (1961), a tale of utopias and illusions set in a Milan headed towards the economic boom; a new and multifaceted context in which people wondered about the rising industrialization and, at the same time, noticed the workers' marginalization and class exploitation. Room neighbors in a boarding house in via Solferino, alongside Ugo Mulas and Bianciardi himself, the two photographers, adventure companions, walked together the first steps in the world of photojournalism in an absolute symbiosis of ideals and research orientations. United by the same combative and bold spirit, in the difficult dealing with the red tapes of the compromised world of publishing, they have both formulated, in the intense partnership of the Milan years, a photographic belief that they have never abandoned; an approach and a method that apart from the differences due to the respective expressive qualities, they have maintained for a long time with exemplary coherence, crossing the national borders, in the experiences lived around the world. Still today, after more than 60 years, the two photographers prove to be faithful to the same idea of photography consecrated to the truth: In Bavagnoli's case, he has now been away from the world of photography for many years, it transpires from the long tales, filled with recollections, that, whatever the experience they are referring to, it moves to or goes back to the peculiar debuts in Italy in the 50s; Dondero, instead, constantly keeps on living in his unstoppable production, always and consistently faithful to that duo of freedom and loyalty, which he, a photographer tout court as he loves to call himself, never stopped pursuing, overcoming whatever obstacle. He is still busy strenuously defending the important role of journalistic reportage as a tool for telling life and the world, despite the discouraging situation of the current market, almost entirely controlled by the capitalist communication, from which he opted to keep at a safe distance; moreover, in the full digital era, Dondero refuses technology, considering it responsible for the constant threat to the faith in descriptive truth, and he bravely opposes to any form of spectacularization in the name of the simplicity and truth of narration, without ever caring too much about the aesthetic aspect. A highly talented person, "an example of civil integrity very unusual to meet in our times”, as Simona Guerra wrote in a recent monograph celebrating him, the photographer is interested in all the life that surrounds him, with a particular attention to dramatic sceneries in war places, to politics and to 
social issues, convinced that photography can offer the precious possibility of being involved and sympathetic witnesses (Guerra, 2011). A firm conviction he began to mature quite early, still is very young, in the early 50s, he wrote as a crime reporter for Avanti!, l'Unità and then Milano Sera; an experience is so fundamental for acquiring the full awareness of the importance of image in communication that he decided to devote himself exclusively to photoreportages and, after a short apprenticeship with the Milan agency Attualfoto, he began to work as a photographer for the magazine Le Ore. The newsweekly, first published in 1953, inspired itself to the great journalistic photography and, above all, it was full of illustrations; its motto said "one picture is worth a thousand words"; a phrase Dondero loved to repeat often ascribing it to Walter Benjamin. Its images were published preserving the independence of the narration, without undergoing the arbitrary selection of a photo editor and without having to be subject to the iconographic criterions imposed by the agencies. Without any censorship, that is, an essential condition for someone who has always professed an austere morality that eschews stereotyped rules and that is never undermined by the logic of success and money. The first important assignment Dondero was given was a reportage on the Reggio Emilia criminal mental asylum, published in the May 1953 issue (see Figure 1). The photographer had managed to show, in his first attempt, that he could tell the truth of facts with great concreteness and immediacy; the report had been realized inside the institution, despite the extreme emergency, and in the several photos, of a great visual impact, each element regarding the formal output was aimed at an efficient restitution of the subject. After the first reportage he was immediately promoted as a photojournalist and, always believing in the same principles, he collaborated with other Italian magazines such as Illustrazione Italiana, Il Mondo, Settimo Giorno, Cinema nuovo, and Epoca. The report made for Cinema Nuovo on the 1954 Venice Film Festival, realized together with Ugo Mulas,and introduced to photography by Dondero himself, is particularly curious and interesting. ${ }^{1}$ The images tell the venetian event far from the limelight and the clamor of the crowd, with the intention of witnessing its impact on the city and its inhabitants: The protagonists are not the famous actors but young people carrying the luggage, or the seaman driving the ferryboat or, again, without any connection to the mundane happening, the workers locked inside Molino Stucky protesting against the threat of closure of the mill (see Figure 2); little text and several images; all the images of the narration, without any cut or manipulation. The strength of the reportage, conceived as a documentation of the present and a civil evidence, derived mainly from the direct contact with people and from the human relationships interwoven and from using photography as a means for approaching life and penetrating the situations, offering a narration with naturalness and truth. Despite a promising career beginning and a rich pay, Dondero decided to quit the magazine and Italy. There was the room for freely telling but it was not enough and it looked always more narrow and limited; the national context did not fulfill the photographer's dream of working for a civil journalism independently. Longing for freedom and knowledge, in 1955 the Genoa photographer moved to Paris, where he thought he would have had more opportunities of growth in his project of photographing life and, above all, as he recalls, since France "saw the concentration of the forces offering the most interesting international photojournalism”. In Paris he started collaborating with some important magazines, among which Le Monde, Le Nouvel Observateur, and Jeune Afrique, becoming famous for the well-known photo taken with the Nouveau

\footnotetext{
${ }^{1}$ Dondero loves to tell, as several interviews stand there to prove, his meeting with Ugo Mulas on a bench of some Milan gardens on the day he had quit his job at the Dealfoto agency, where he wrote captions. It was the occasion for putting the camera on his friend's hands and for beginning to work together in the name of a committed photoreportage.
} 
Roman writers; ${ }^{2}$ then he returned to Italy, in Rome, in the 1960s, finding in the city of Pasolini, Moravia and Flaiano the ideal basis for touring the world and being always present at the most important events of history and politics and for keeping on following his humanist vocation and cultivating his passion for social reportages.

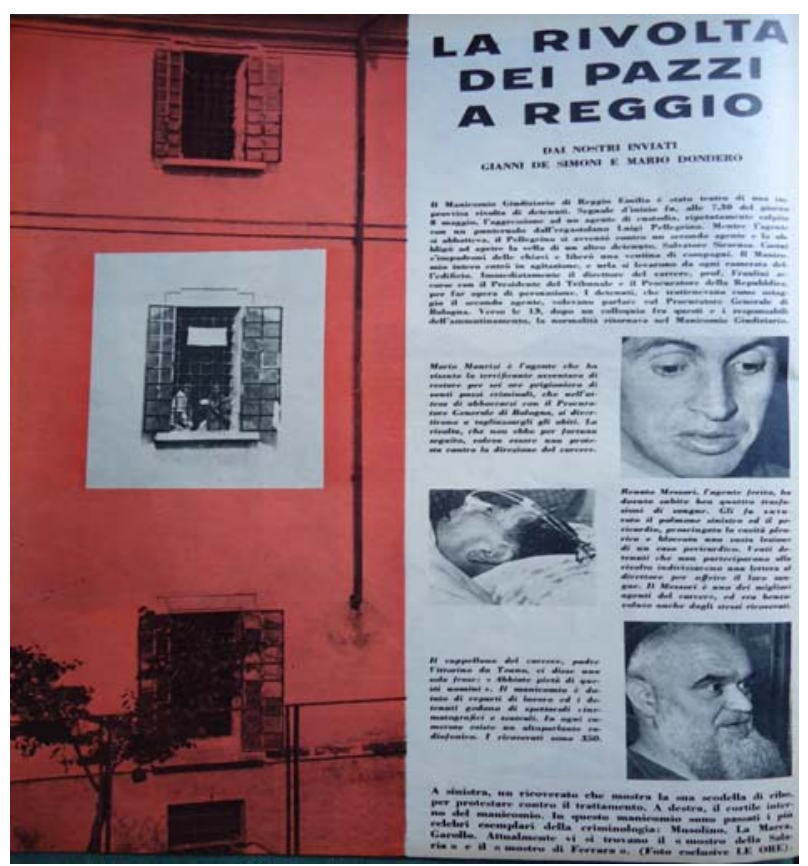

Figure 1. Page of Le Ore. Settimanale fotografico d’informazione, 15 May 1953.

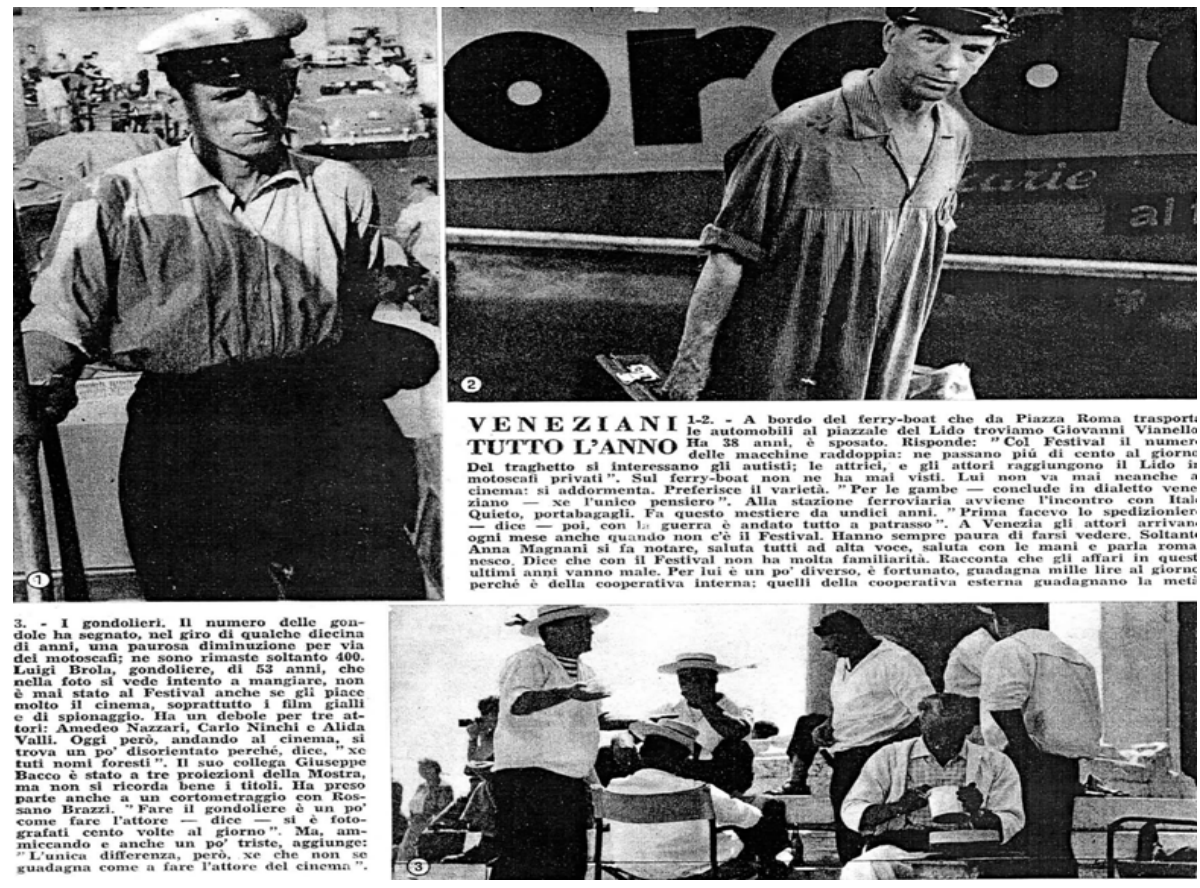

Figure 2. Page of Cinema Nuovo, September 1954.

\footnotetext{
${ }^{2}$ In Paris Dondero had the idea of photographing the protagonists of the Nouveau Roman all together (Alain-Robbe Grillet, Claude Simon, Claude Mauriac, Robert Pinget, Samuel Beckett, Nathalie Sarraute) for a reportage to be published on L'Illustrazione italiana. Jêrome Lindon, the publisher of the Editions de Minuit, helped him to gather them all together.
} 
The human and professional story of his friend Carlo Bavagnoli follows a parallel track; they both shared the experience in Milan with the same enthusiasm and the same faith, and, most of all, the same social commitment; with the experience of the publication of the first photo reports of social investigation for the magazines, but also the long night walks photographing the suburbs in the Porta Romana area. Then, the departure from the national context followed with the employment by Life, the prestigious American magazine, where Bavagnoli was the only Italian photographer to ever become a steady member of the editing staff, and a professional growth always faithful to the humanistic reportage genre (Ladogana, 2010). After the first reportages for Settimo Giorno, Cinema Nuovo, and L'Illustrazione italiana, the photographer from Piacenza started his important work experience with the weekly Epoca, lasted from 1955 to 1958. "At Epoca there was no kind of ideological and political control and a tendency to propose always innovative things prevailed", telling the photographer while specifying, with a still today particularly vigorous ardor, that the magazine, under Enzo Biagi's co-direction "was the only one in Italy offering the narration of a lived life, the real one"; for the rest, as Bavagnoli bitterly says, "in Italy most of the newsmagazines published political statements rather than photographs", aiming in particular at Pannunzio's Il Mondo and at the photographs disconnected by the sequences, usually combined with captions that heavily affected the reading. ${ }^{3}$ In the several reportages made for Epoca, the narrative nature and the importance of narration stand out, together with a feeling of empathy and immediacy towards the described reality, with an approach sensibly moving away from the awareness strategy typical of the neorealist language (Ladogana, 2012). An approach coherently persists also when Bavagnoli was involved by l'Espresso in a collaboration with the important and in-depth parliamentary inquiry on the miserable conditions of Southern Italy, entitled "Africa at home” and published between April and May 1959. In that occasion, the photographer was sent on an expedition in the villages of Loculi, Irgoli, and Onifai, in the inner areas of Sardinia; his reportage was welcomed, as he loves recalling, with great satisfaction by the editor, Arrigo Benedetti, so that one of his photographs even made the cover of the magazine. However, despite the considerable room reserved to his photographs, l'Espresso did not publish the whole reportage: In fact, they used only the images closer to a stereotype of misery, aimed at causing a prevailing feeling of compassion on the readers, thus responding to a precise ideological plan. On the other hand, all the photographs lacking a moving effect and a compassionate stretching were discarded; those images mostly faithful to a representation of the referential context in all its multiformity and uniqueness, originated from a will of knowledge and a documentary intent that did not need any framing trickery. In the shots, the visual field offers, through a substantial quantity of elements, a richness of cultural information that generally tells the life in the southern villages, without naturally omitting the ruling aspect of misery (see Figures 3 and 4). For its descriptive nature, for its peculiar attention to detail and, mostly, for its distance from whatever kind of strumentalization, the whole reportage could be compared to what in photography was described as "ethnographic realism" (Faeta, 2006). This one is a genre opposed to the neorealist approach, from which it moves away evidently not for a difference in the contents as much as for the models of representation.

\footnotetext{
${ }^{3}$ Bavagnoli's quotations are taken from two interviews made to him by the writer in 2010 and 2014.
} 


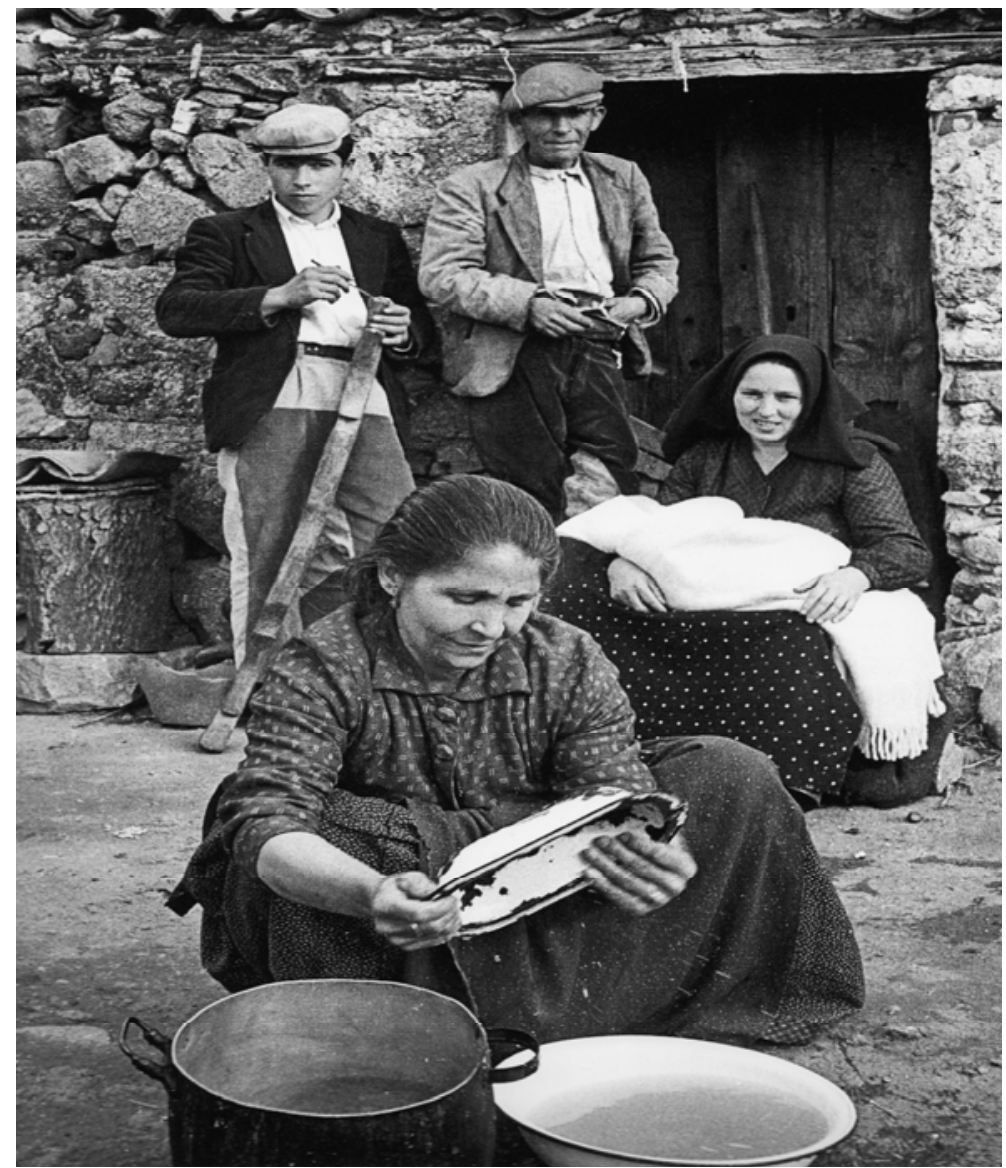

Figure 3. Loculi, Sardinia, 1959. Reportege of Carlo Bavagnoli (Courtesy, ARCHIVIO ILISSO EDIZIONI NUORO).

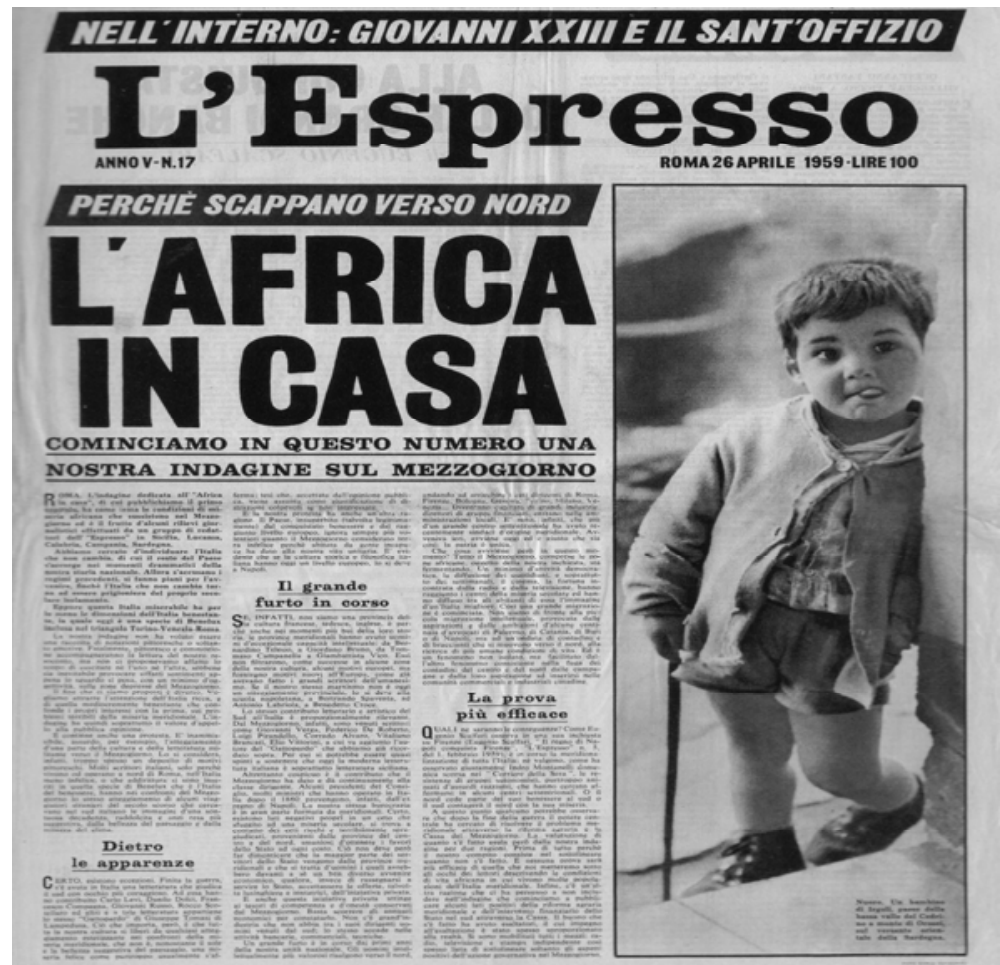

Figure 4. Page of L’Espresso, n. 17, 26 April 1959. 
Each Bavagnoli's documentary image distinguishes itself for its peculiar aesthetic strength: "I loved to tell life without set plans, I did not need to come up with artificial photos, I just had to be creative”. A statement can be connected to the complexity of theories relative to the interpretative vocation of photography, to its being uniquely afferent to its author, to his eye and to the situation he created. The photographer's personal interest in a human story full of life, immersed in the moments of life that photography succeeds catching and always conceived as a sequence, so that no image might look more emblematic than another, had been clearly outlined since the first Milan attempts and it will bear the best fruits in the personal projects rather than in the reportages on order for the journalistic press. Those are long research works that were mostly published on photographic books; among them, a particular importance was acquired by "Gente di Trastevere” (People from Trastevere), published by Mondadori in 1963 and containing a long reportage on the people of the Roman area thanks to which Bavagnoli succeeded crossing the Ocean and being hired by Life. Still today, his souvenirs of the American years, the permanence in the staff of the magazine for more than 10 years, are essentially tales of freedom, of a world where one could work without fearing that the photos taken would be modified and strumentalized and where the only selective criterion was constituted by the high quality of the images.

The same freedom Dondero had managed to find as a free-lance and maintaining an absolute independence, working just for those progressive and committed magazines respectful of the dignity of the photographic work and of the professional autonomy.

The Italian context had offered the two young talents the opportunity of making a formative experience decisive for their future journey; in the few years, the national publishing industry had managed to walk in step with the most updated European and American trends, living the short but intense season of narrative realism. This is also true for a whole generation of photographers provided with an intellectual and creative strength that contributed in leaving to posterity an extraordinarily varied and undoubtedly true image of a new democratic Italy: from the evidences of the new industrial reality to the working class suburbs in the northern cities to a long array of reportages made in Southern Italy, during the long travels southwards of great photographers, from Pablo Volta to Ermanno Rea, from Plinio De Martiis to Franco Pinna and Caio Garruba.

The fruitful season of Italian neorealism, already over in the second half of the 1950s, nourished a photographic documentarism sui generis that, despite the censorship of a system slave of the intensification of the clash between the political strengths, succeeded imposing itself and preparing the ground for the future development of a much more evolved informative photography. A documentarism that only in the late 1960s, especially with the reopening of the political debate in 1968, could find a place in the best Italian daily press (Corriere della Sera, Stampa, Unità, Giorno), but also in the great newsmagazines, with a new mastery and awareness of the photographic means, derived from the experimentation of original visual languages and, above all, from the now acquired and deep knowledge of the great models of European communication (Lucas, 2005).

\section{Conclusion}

The human and professional stories of Carlo Bavagnoli and Mario Dondero follow a parallel track; they both shared the italian experience with the same enthusiasm and the same faith, and, most of all, the same social commitment: the experience of the publication of the first photo reports of social investigation for the magazines, but also the long night walks photographing the suburbs in the Porta Romana area. A spirit of 
documentation founded on the direct and immediate taking of current events, always linked at the importance of narration. Their work testifies to the big magnum's photographers' influence.

\section{References}

Agliani, T., Dangelo, S., Lucas, U., \& Tadini, E. (2012). Jamaica: Art and life in the heart of Brera. Milano: Rizzoli.

Bavagnoli, C. (1963). People of Trastevere. Milano: Mondadori.

Bavagnoli, C. (2000). The Archive, Photographs, books, 1954 al 1995. Parma, Fondazione Cassa di Risparmio di Parma e Monte di Credito su Pegno di Busseto: Grafiche Step.

Carlotti, A. L. (2001). Photography and Photographers in Milan from XIX Century to today. Milano: Abitare Segesta.

Colombo, A. (1982). Anger, poetry, engagement in thirty years. Milano: Editrice Progresso.

Colombo, A., \& Piovani, G. (1980). Progresso fotografico. Milano: Editrice Progresso.

De Marco, D. (2008). Dondero 4/20. Udine: Forum.

Del Buono, O. (2001). Writing with Laica: Federico Patellani (pp. 116-118). In A. L. Parlotti (Ed.), Photography and Photographers in Milan from XIX Century to today. Milano: Abitare Segesta.

Faeta, F. (2003). Strategies of the eye: Essays of visual ethnography. Milano: Franco Angeli.

Faeta, F. (2006). Photographers and photographs: An antropogical view. Milano: Franco Angeli.

Faeta, F. (2009). "Slipping out of time" Images of Sardinia in the Second World War. In M. Miraglia (Ed.), The photography in Sardinia. The external view. The years of postwar. Nuoro: Ilisso

Ferracuti, A. (2005). The trade of memory: Conversation with Mario Dondero. E. Il mensile di Emergency, 5, 40-51.

Ferracuti, A., \& Raffaeli, M. (2008). Donderoad: The Mario Dondero's writhers. Ancona: Cattedrale.

Gnoli, A., \& Ferracuti, A. (2010). Mario Dondero about view, about life: A film in XX Centuty. Bergamo: Lubrina Editore.

Guerra, S. (2011). Mario Dondero. Milano: Mondadori.

Ladogana, R. (2010). Orani 1958. The images by Bavagnoli describe Nivola (pp. 17-23). In M. Volpi, M. L. Frongia, \& R. Ladogana (Eds.), Carlo Bavagnoli. Costantino Nivola. Return to Itaca. Nuoro: Ilisso Edizioni.

Ladogana, R. (2012). Twenty years of photographic reportage from Epoca to Life. Rivista elettronica di Archeologia e Arte, Supp. 1, 735-744.

Lucas, U. (2004). The History of Italy. Annali 20. Photography 1945-2000. Torino: Einaudi.

Lucas, U. (2005). Photojournalism in Italy 1945-2005: Trend lines and routes. Torino: La Stampa.

Lugon, O. (2008). The photo documentary: From August Sander to Walker Evans. Milano: Electa.

Marmori, G. (1960). The defenders of anti novel. L'Illustrazione Italiana. Febbraio, 59-65.

Messner, R. (1994). A way of life in a world to live. Milano: Belvedere.

Quintavalle, A. C. (1973). Conversation with Ugo Mulas. In A. C. Quintavalle (Ed.), Ugo Mulas. Images and Writing. Parma: Università.

Ria, A. (2003). Mario Dondero. A human comedy. Portraits and reportages. Losone: Le Ricerche.

Russo, A. (2011). Cultural history of Italian photography from Neorealism to Postmodern. Torino: Einaudi.

Salinari, C. (1960). The question of realism. Firenze: Parenti. 